\title{
The Department of Education and Culture's Strategy to Address Educator Shortage in Pontianak
}

\author{
Rahmawati Sururama1, Valentino Christ Vowell²
}

DOI: $10.35445 /$ alishlah.v13i3.1441

\begin{abstract}
Article Info
Abstract

Keywords: Analysis; Strategy; Educators

The purpose of this research was to examine the Department of Education and Culture's strategy for addressing the city of Pontianak's teacher shortage. This study employs an inductive descriptive qualitative method. Data reduction methods, data display/data presentation, and conclusion drawing/verification were used to analyze the collected data. In order to gather the data, we used a combination of observation, documentation, and in-depth interviews as data collection techniques. Structured interviews and purposive sampling were used to select participants for the study. Research shows that the Department of Education and Culture's strategy for dealing with the shortage of teachers is adequate. There is no doubt that the Department of Education and Culture is doing everything it can to alleviate the shortage of teachers in Pontianak City, whether it's through policies like hiring PPPK employees or stipulating that ASN be formed exclusively for educators.
\end{abstract}

Kata kunci:

Analisis;

Strategi;

Pendidik

\begin{abstract}
Abstrak
Penelitian ini bertujuan untuk menganalisis strategi Dinas Pendidikan dan Kebudayaan dalam mengatasi kekurangan tenaga pendidik di kota Pontianak. Dalam penelitian ini, digunakan metode deskriptif kualitatif dengan pendekatan induktif. Data yang diperoleh dianalisis dengan menggunakan metode reduksi data, penyajian data, dan penarikan kesimpulan/verifikasi. Teknik pengumpulan data dilakukan dengan menggunakan metode observasi, dokumentasi, dan wawancara. Wawancara dilakukan secara terstruktur, dan penentuan informan dilakukan secara purposive sampling. Berdasarkan data penelitian, dapat disimpulkan bahwa Strategi Dinas Pendidikan dan Kebudayaan dalam mengatasi kekurangan tenaga pendidik sudah baik. Dinas Pendidikan dan Kebudayaan dalam mengatasi setiap kendala penanggulangan kemiskinan tenaga pendidik sudah cukup baik untuk dapat membuat kebijakan seperti rekrutmen tenaga PPPK dan menetapkan bahwa pembentukan ASN khusus untuk tenaga pendidik, dimana setiap strategi yang dilakukan dapat mengatasi masalah kekurangan tenaga pendidik di kota Pontianak.
\end{abstract}

\section{INTRODUCTION}

Educators play a critical role in the advancement of a nation by developing human resources hierarchically and in various ways. This is consistent with the Indonesian people's aspirations, as stated in the fourth paragraph of the 1945 Constitution of the Republic of Indonesia, which states that the government protects each citizen's right to develop through education, with the resulting

\footnotetext{
${ }^{1}$ Institut Pemerintahan Dalam Negeri (IPDN), Sumedang, Indonesia

Email: rahmawatisururama@ipdn.ac.id

${ }^{2}$ Pemerintah Kota Pontianak, Indonesia

Email: valentinochristvowell@gmail.com
} 
benefits increasing the standard of living and well-being. Given the critical role of educators, it is necessary to enhance the quality and effectiveness of these educators in order to maintain a balance in the knowledge transfer process by aligning the development of science and information technology with educators' insights, skills, and abilities. Of course, this will improve the quality of existing education (Risna \& Nur, 2021; Harris et al.,2021). Education is significantly influenced by the quality of educators (Singh et al., 2021). One of the critical enabling factors for sustainable development is high-quality education, both formal and informal, that is accessible to all and beneficial to the public (Garca et al., 2020; Pan et al., 2020).

In supporting this, as a form of concern, the government allocates $20 \%$ of the State Revenue and Expenditure Budget (APBN) for the education budget based on the law's mandate. However, from a report entitled How Indonesia's Subnational Government Spend Their Money on Education released by the World Bank, it was found that the most allocated for teacher salaries and allowances was $86 \%$ and the rest for the remaining the development of the quality of education. This is unfortunate because many educators still need development in improving the quality of education and do not yet have certification, and teaching is not following their qualifications. Development is a series of continuous activities and is needed by educators in supporting their main tasks and functions that are adapted to existing developments (Dinkelman, 2011; Jiang \& Shi, 2019).

According to the Ministry of Education and Culture data, the City of Pontianak (2019) has 113 public and 52 private elementary schools. There are also 28 public middle schools and 50 private middle schools in the district. The main data set includes fifty public high schools and ten private schools. From the 327 public and private schools in Pontianak City, it is known that the number of educators with the status of civil servants is less than the number of educators without the status of civil servants. This affects educator certification and the quality of education, as one indicator is the ratio of educators to students, specifically for elementary, junior high, and the ideal high school ratio of 20:1, where one teacher teaches 20 students. According to observations and existing data, there was a shortage of approximately 557 elementary school educators in the City of Pontianak in 2017, which increased to 700 in 2018, and a shortage of 329 junior high school educators in 2017. In 2018, it increased to 360 people, including retirees, from an annual average of 200-300 teachers.

Researchers have conducted a number of studies on the topic of the teacher shortage. Teacher shortages can be alleviated by providing students with a well-rounded education that emphasizes both content knowledge and practical skills. A study by Puspita (2020) examines how East Kalimantan's provincial office for education and culture is helping to improve Samarinda City's vocational high school teachers. Priambodo (2018) used geographic information systems (GIS) to create world maps. For the city of ternate, Rajaloa (2018) studied the management and recruitment of educators. Since previous studies have focused on the lack of educators in Pontianak City, West Kalimantan Province, this study focuses on the Department of Education and Culture's strategy for overcoming this problem.

\section{METHODS}

The author uses a descriptive qualitative method with an inductive approach in this study. Qualitative research is an in-depth observation of social conditions both in terms of individuals and society (Creswell, 2014; Nurfalah, 2021). The data obtained were analyzed using data reduction methods, data display/data presentation, and conclusion drawing/verification (Miles, M.B, Huberman, A.M, \& Saldana, 2014; Liu et al.,2021). Data collection techniques were carried out using the methods of observation, documentation, and interviews. Interviews were conducted in a structured manner, and the informants were determined through purposive sampling.

The purposive sampling technique in qualitative research, according to Sugiyono (2017), is a sampling technique for data sources with specific considerations. This particular consideration is usually the person who knows best about what we expect, or perhaps as the master of information to make it easier for researchers to find the object or situation under study. 
Table 1. Informant List

\begin{tabular}{|c|c|c|}
\hline No & Informant & $\begin{array}{l}\text { Number of } \\
\text { People }\end{array}$ \\
\hline 1 & Head of Department of Education & 1 \\
\hline 2 & Secretary of the Department of Education & 1 \\
\hline 3 & Head of Basic Education Development & 1 \\
\hline 4 & Head of Education and Education Personnel & 1 \\
\hline 5 & Section Head of Educator Development & 1 \\
\hline 6 & Head of Section for the Development of Education Personnel & 1 \\
\hline 7 & Elementary School Principal & 16 \\
\hline 8 & Junior High School Principal & 6 \\
\hline 9 & High School Principal & 5 \\
\hline 10 & Teacher & 15 \\
\hline \multicolumn{2}{|r|}{ Amount } & 48 \\
\hline
\end{tabular}

Source: data proceed

\section{FINDINGS AND DISCUSSION}

The researcher uses the Strategy theory from Koteen in Salusu (Salusu, 2008) to measure the Department of Education and Culture strategy through the dimensions in view, namely: Organizational Strategy, Program Strategy, Supporting Strategy, and Institutional Strategy.

\section{Organizational Strategy}

This strategy relates to formulating the process's mission, goals, values, and innovation. The scope related to this is about what should be done and for whom to realize the organization's ideals. The organization's strategy is seen from leader's strategy in overcoming the lack of educators. From the results of existing research in overcoming the shortage of educators, the Head of the Education and Culture Office as the leader took the initiative to provide flexibility and authority to each school principal in recruiting honorary staff to cover the shortage of educators with the help of BOSDA funds (School Operational Assistance). This is done because the regions have to wait for policies from the center in the procurement of educators, which takes time. The location of decision making in the implementation of teacher governance policies, especially related to the provision of teachers equally, involves various parties ranging from schools, local governments, and central governments such as the Ministry of Education, Ministry of PANRB, BKN, and Ministry of Finance (Lestari \& Nugroho, 2021; Berisha et al.,2019). The teacher recruitment system (teaching staff) can be carried out in various ways. Namely, recruitment is carried out by the principal by confirming to the Education and Culture Office, which in terms of salary is obtained from BOS funds or APBN funds (Putri \& Karwanto, 2021; Baskoro et al.,2018).

\section{Implementation of the Education Office's Program Strategy in Overcoming the Lack of Educators}

The program in question is a series of planned and integrated activities to support an organization's goals, objectives, vision, and mission. Some of the main activities set out to describe several programs in overcoming the shortage of educators are as follows:

a. The strategy of the Dinas in making decisions to address the need of educators

From the research results, there are strategies carried out by the Department, namely by collecting data, structuring, and equalizing. Data collection was carried out by re-checking the number of educators so that data on the number of shortages of educators from each school in the Pontianak City area could be seen; the next stage was proposing the formation of Candidates for Civil Servants to the central government. From the data collection results, the number of shortages of educators in Pontianak City is 1023 people. Still, not all of the proposals will be included because they have to go through several processes. The arrangement is carried out after there is certainty about the number of educators. The last stage is equity; what is meant by equity is where educators who have gone through data collection, arrangement, and formation will be distributed according to 
the needs and competencies of the educators. The primary purpose of structuring and equity is to reorganize the needs of teachers in the education unit so that they are rational to create an equitable and balanced education, and the educational process can run effectively and efficiently so that in the end, there is a common standard of educational outcomes (Andhika \& Iswahyudi, 2021; Ozarkib \& Yakovenko, 2020). The uneven distribution of teachers due to easy transfers is due to weak government supervision of the flow of teacher transfers (Andina \& Arifa, 2021); this is also due to teachers being unwilling or refusing to be transferred to schools with lower quality or accreditation than the original teaching place. Teachers who have settled around the old teaching place, and there is a request for teachers to be transferred to certain schools (Kilatsih et al., 2019; Gay et al.,2020).

b. Department's strategy in improving the quality of educators

Human resource development plays a significant role in the implications of the quality of educators. Qualified human resources can support activities more effectively and efficiently; this can be seen from educators' abilities, skills, and competencies. Human resource development to improve the quality of educators can be obtained through the education and training of educators. Teacher competence is an essential component in learning (Leonard, 2015). From the results of existing research, it is known that the Pontianak City Education and Culture Office has carried out the development of teaching staff by involving educators in workshop activities, large-scale technical guidance in the Pontianak City area, and several other activities such as MGMP (Subject Teacher Consultation), at the level of High School has MKS (School Principals Consultation), and $\mathrm{K}_{3} \mathrm{~S}$ (Principal Working Group) where this activity is to improve the quality and quality of the principal himself, then for the teachers themselves a KKG (Teacher Working Group) is formed both from the top level to the top level. lower level. Human resource development is closely related to efforts to improve organizational members' knowledge, abilities, attitudes, and career paths supported by organizational flexibility in achieving organizational goals (Krismiyati, 2017).

\section{Strategies for Supporting the Education Office in Overcoming the Lack of Educators}

This support strategy focuses on maximizing the utilization of available essential resources to improve the quality of organizational performance, where existing resources can be in the form of human resources, finance, technology, and so on. The use of resources establishes relationships in schools; this is reflected in the school's organizational structure, which becomes a formal system of task and authority relationships that control how each works together to manage all available resources to realize organizational goals. In this case, the researchers looked at the available human resources, namely educators in the education unit. From the results of interviews and observations that have been made, the human resources available at the Department of Education and Culture can already support the capacity building of the educators themselves; this is evidenced by being part of workshops and various training activities. As for the human resources of the educators themselves to participate in the fulfilment of the Candidates for Civil Servants formation, it is felt that they are ready to fulfil the part of the educators in the city of Pontianak. However, the problem is the number of formations that will eventually be accepted as Candidates for Civil Servants, which must be willing to take every policy and support every program from the Department of Education and Culture to advance education in Pontianak City.

\section{Implementation of the Education Office's Institutional Strategy in Overcoming the Lack of Educators}

a) Standardization of Recruitment of Educators

According to the study's findings, the criteria for hiring educators in the City of Pontianak follow the set arrangement, formation, and determination, and the Department of Education and Culture has carried out these activities in accordance with the rules and directives of the City of Pontianak, and the recruitment of educators itself necessitates educators who have the ability in their field. It is impossible to separate the process of finding and hiring new employees from the needs of interested parties or agencies (Khumalo \& Serpa, 2021). Study (Bulger et al., 2014) found that 
prospective educators should be recruited by looking at the literature on these criteria. In order to find a suitable candidate for teaching, it is necessary to identify the characteristics of potential teachers, to adjust the basic principles that have been set, and finally, to recruit educators as needed. As a series of activities involving the evaluation of human resources, recruitment is concerned with identifying the skills, competencies, and qualifications required by each relevant agency in order to implement institutional strategies and carry out the initiation of policy formulation in accordance with government standards for filling educator quotas that remain unfulfilled in Pontianak City. The first step in hiring new teachers is to determine the educational needs of the school's faculty. This activity helps the agency meet its needs by assessing internal and external factors and analyzing available teaching resources. In this analysis, the abilities and skills required to complete the task are outlined in the job specifications, while the job descriptions detail the responsibilities of the employee. On the other hand, an employer's job description outlines the specific duties an employee will be expected to perform (Rajaloa \& Hasyim, 2018).

According to research conducted by the Department of Education and Culture, facilities for educators who wish to pursue certification, as well as guidance on thesis preparation for qualified and competent educators, are provided to those who meet the requirements in this case, if they meet the requirements set in this case. Employee performance is greatly influenced by employee motivation (Robert \& Melinda, 2018). According to the study's findings, educators from the Department of Education and Culture are not only trained but also provided with educational support. If that is the case, then education can greatly benefit the careers of educators through a variety of mechanisms. (Karagiorgi \& Nicolaidou, 2013). Teachers must have academic qualifications, competence, educator certification, be physically and mentally healthy, and have the ability to achieve national education goals (Lita, 2019).

Based on the legalistic analysis of the Pontianak City RPJMD 2015-2019, the city of Pontianak is as follows:

1. Improving the Quality of Educators and Educators

Improving the quality of educators and teaching staff is an essential part of advancing education in Pontianak. In this case, the existing educational background strongly influences reliable and quality human resources. Education makes human resources more understanding and faster in the face of changing times. The following are some indicators that influence the improvement of the quality of educators and teaching staff.

a) The ratio of Elementary/Junior High/School Teachers to Students

The ratio of teachers to students indicates how the facilities and infrastructure are evenly distributed. The teacher-student ratio basically can be interpreted as a comparison of the number of students and teachers in the education level, if the high ratio will affect learning effectiveness. The following table of the teacher to student ratios:

Table 2. Teacher To Student Ratio

\begin{tabular}{|c|c|c|c|c|c|c|}
\hline \multirow[b]{2}{*}{ No } & \multirow[b]{2}{*}{ Region } & \multicolumn{5}{|c|}{ TEACHER - STUDENT RATIO } \\
\hline & & $\begin{array}{l}\text { Teachers } \\
\text { Elementa } \\
\text { ry School } \\
\text { Students }\end{array}$ & $\begin{array}{l}\text { Teachers } \\
\text { Middle } \\
\text { School } \\
\text { Students }\end{array}$ & $\begin{array}{c}\text { Teacher } \\
\text { High } \\
\text { School } \\
\text { Student }\end{array}$ & $\begin{array}{c}\text { Teachers } \\
\text { Vocational High } \\
\text { School Students }\end{array}$ & Amount \\
\hline 1 & West Pontianak & 25 & 20 & 15 & 14 & 74 \\
\hline 2 & Pontianak City & 21 & 17 & 16 & 17 & 71 \\
\hline 3 & South Pontianak & 20 & 19 & 17 & 17 & 73 \\
\hline 4 & Southeast Pontianak & 18 & 14 & 16 & o & 48 \\
\hline 5 & East Pontianak & 22 & 20 & 20 & 20 & 82 \\
\hline 6 & North Pontianak & 22 & 21 & 20 & 15 & 78 \\
\hline & West Kalimantan & 22 & 19 & $\mathbf{1 7}$ & 16 & 426 \\
\hline
\end{tabular}

Source: Department of Education and Culture in 2019 
As shown in the chart above, elementary school teachers can teach as many as 25 students in a single class, which means that the number of students being taught is less ideal than it should be because the perfect number of students in a class to be taught is 25 students. However, for several subdistricts in Pontianak Ci, the number of students taught by a single teacher at the junior high school level is 20 students, which is already ideal. This holds true for all levels of education, including high school and vocational training. Several sub-districts in Pontianak remain unsuitable for high school students who are taught, which has an effect on the effectiveness and efficiency of the classroom learning process. Interview results show that the number of teachers to students has a significant impact on the current learning process. If it is too high, the teaching process will be less effective. Teaching and learning become inefficient when one teacher teaches a small number of students.

Based on this, the conclusion that can be drawn is to achieve the effectiveness and efficiency of the teacher to student ratio, the need for equal distribution of the number of existing educators through the determination, mapping, and formation of educators in the city of Pontianak.

b) The number of civil servants who take part in formal training and technical guidance for civil servants

Based on the 2019 RENJA (Work Plan), the projected number of civil servants who will participate in the Formal Training and Technical Bimtek is 30 people formed in the RPJMD of the Education and Culture Office. With the determination of the formation of the number of civil servants participating in this activity, it is hoped that it will be able to support the educational process in the Pontianak City area and develop human resource capabilities.

2. Teacher Mapping and Formation Arrangement

Mapping educators is an integral part of determining the number of educators who will be in a formation. If it is fulfilled, then it will then be analyzed again based on the number of mappings that can be seen following Law No. 14 of 2005 concerning Teachers and Lecturers, on condition that as follows:

a) The appointment and placement of educators is carried out objectively and transparently, following the laws and regulations

b) Selection and order of teachers in academic units organized by the government following government regulations.

c) Existing administrators carry out the appointment and placement of teachers in educational units in the community following existing agreements.

d) Teachers who are appointed can be placed in existing structural positions.

Table 5. Retirement Projected Educator Data

\begin{tabular}{lccccccc}
\hline No & Region & $\mathbf{2 0 1 9}$ & $\mathbf{2 0 2 0}$ & $\mathbf{2 0 2 1}$ & $\mathbf{2 0 2 2}$ & $\mathbf{2 0 2 3}$ & Amount \\
\hline $\mathbf{1}$ & $\mathbf{2}$ & $\mathbf{3}$ & $\mathbf{4}$ & $\mathbf{5}$ & $\mathbf{6}$ & 7 & $\mathbf{8}$ \\
$\mathbf{1}$ & West Pontianak & 32 & 33 & 53 & 61 & 60 & 239 \\
2 & Pontianak City & 27 & 35 & 53 & 51 & 48 & 214 \\
3 & South Pontianak & 39 & 34 & 54 & 58 & 59 & 244 \\
4 & Southeast Pontianak & 9 & 10 & 15 & 25 & 14 & 73 \\
5 & East Pontianak & $\mathbf{1 1}$ & 11 & 27 & 35 & 31 & $\mathbf{1 1 5}$ \\
6 & North Pontianak & 34 & $\mathbf{2 8}$ & 44 & 31 & 43 & $\mathbf{1 8 0}$ \\
& West Kalimantan & $\mathbf{1 5 2}$ & $\mathbf{1 5 1}$ & $\mathbf{2 4 6}$ & $\mathbf{2 6 1}$ & $\mathbf{2 5 5}$ & $\mathbf{1 0 6 5}$ \\
\hline
\end{tabular}

Source: Department of Education and Culture in 2019

Human resources, especially teachers, are needed based on interviews and observations. Every year, the number of retired educators continues to grow to meet the needs of educators is very large. Still, the regions depend on decisions that the central government will issue, and then the moratorium is also a barrier in fulfilling educators. The thing that the Pontianak City government 
can do is to recruit first-aid workers based on a predetermined decree. Still, the number of PPPK that can be accepted is only 11 people. The data for admissions are included in the Dapodik data (Education Principal Data) Ministry of Education and Culture City government policies Pontianak. At the same time, the ASN formation will only focus on teacher formation. PPPK is allegedly able to accommodate superior and professional human resources to answer the 'chaotic' competence and professionalism of State Apparatus HR in the bureaucracy in Indonesia (Qomarani, 2020).

\section{Supporting and Inhibiting Factors for the Strategy of the Department of Education and Culture}

a. Supporting factors

In carrying out their duties and to achieve organizational goals that are supporting in overcoming the shortage of educators based on the results of research conducted, namely:

1) Through the use of BOSDA funds from the Pontianak City Government, schools can hire as many educators as they need by recruiting honorary staff members..

2) MGMP (Subject Teacher Consultation), MKS (Principal Consultation) for high school, $\mathrm{K}_{3} \mathrm{~S}$ (Principal Working Group) for elementary school, and teachers KKG activities (Teacher Working Group) are carried out (Teacher Working Group) for all teachers. Conducting coaching and building capacity for education and education personnel.

3) Things that can be done to improve the well-being of educators and education staff include assisting with guidance from State Universities and providing advice on the writing of scientific papers.

b. Obstacle Factor

Several factors hinder the Department of Education and Culture in overcoming the lack of educators; the results of research that has been carried out are as follows:

1) The existing limitation in overcoming the lack of educators in Pontianak City is that the education office needs to wait for a decision on the formation accepted by the central government, which is still not fully fulfilled because the moratorium is a barrier to meeting the needs of educators.

2) Many teachers retire each year, which makes it difficult to keep up with the demand. There will still be a shortage of educators if the quotas for the various formations are not met in full.

3) There are still educators who are still not following their abilities. This is because the number of the teacher-student ratios is small, which will affect the effectiveness and efficiency of the teaching process to students. The percentage of teachers and students turns out to affect the human development index (Sangkereng et al., 2019).

\section{Efforts to Overcome Inhibiting Factors in Overcoming the Strategy of Lack of Educators}

In overcoming the lack of educators, there is an inhibiting factor, but this can be overcome by implementing various strategies that can minimize these factors, as stated by the Mayor of Pontianak, Edi Rusdi Kamtono, namely:

1) Although only eleven PPPK workers have been hired, the Pontianak City Government is hopeful that this will be a good start in addressing the city's educator shortage. Their data has already been entered into the Ministry of Education and Culture's Dapodik (Data Principal Education).

2) The Pontianak City Education and Culture Office then granted full authority to schools to recruit teachers using the funds it provided. It is thus possible to overcome the shortage of teachers in Pontianak by making some efforts.

As a result, the Pontianak City government can completely overcome the overall shortage of educators by completing ASN formations, particularly for teachers. 


\section{CONCLUSION}

The Department of Education and Culture's strategy for addressing the educator shortage is sound, as evidenced by the Department's procedure, subsequent decisions and programs to address the educator shortage, and how the Department of Education and Culture improves the quality and competence of educators, specifically teachers, in accordance with the program implemented. Naturally, there will be a supporting and a hindering factor in implementing the strategy to address the educator shortage in Pontianak City. By implementing the task strategy and meeting existing targets, the Pontianak City Education and Culture Office has been able to develop programs that are extremely beneficial as part of the Department's strategy for advancing educator welfare and educator quality, as well as overcoming the Office of Education and Culture's inhibiting factors. Education and culture benefit from developing and implementing activities and programs. The Department of Education and Culture has been successful in overcoming every obstacle to addressing the educator shortage to the point where it can implement policies such as the recruitment of first-aid workers and stipulate that the formation of ASN is specifically for educators, where every strategy implemented can address the issue of teacher shortage.

\section{REFERENCES}

Andhika, A. E. P. (2021). Strategi Dinas Pendidikan Dan Kebudayaan Dalam Pemerataan Tenaga Pendidik Untuk Memenuhi Standar Pelayanan Minimal Pendidikan Dasar Di Kabupaten Biak Numfor. Gema Kampus IISIP YAPIS Biak, 16(1), 46-58.

Andina, E., \& Arifa, F. N. (2021). Problematika Seleksi dan Rekrutmen Guru Pemerintah di Indonesia. Aspirasi: Jurnal Masalah-masalah Sosial, 12(1), 85-105.

Baskoro, B. Y., Harun, C. Z., \& Ibrahim, S. (2018, October). Strategy for Increasing Human Resources and Employee Productivity Services in Scientific Education and Training Center Service Malahayati Aceh. In 3rd International Conference on Educational Management and Administration (CoEMA 2018) (pp. 51-53). Atlantis Press.

Berisha, H., Mustafa, S., \& Ismail, Y. (2018). Strategy as practice: An organizational culture approach in a higher education institution in Kosovo. Journal of Educational and Social Research, 8(3), 37-37.

Bulger, S., Jones, E. M., Taliaferro, A. R., \& Wayda, V. (2015). If you build it, they will come (or not): Going the distance in teacher candidate recruitment. Quest, 67(1), 73-92.

Creswell, J. W., \& Creswell, J. D. (2017). Research design: Qualitative, quantitative, and mixed methods approach. Sage publications.

Dewanto, S. A., \& Marwanti, M. (2017). Program Kompetensi Ganda Untuk Mengatasi Kekurangan Guru Produktif di SMK. Prosiding Pendidikan Teknik Boga Busana, 12(1).

Dinkelman, T. (2011). Forming a teacher educator identity: Uncertain standards, practice, and relationships. Journal of education for teaching, 37(3), 309-323.

Gay, M., Ahmad, I., \& Ismail, J. (2020). Bari Culture: An Integrated-Collaborative Learning Strategy of Writing Exposition Text. LANGUAGE: Journal of Linguistics, Literature, and Language Education, 3(2), 18-25.

González García, E., Colomo Magaña, E., \& Cívico Ariza, A. (2020). Quality education as a sustainable development goal in the context of 2030 agenda: Bibliometric approach. Sustainability, 12(15), 5884.

Jiang, T., \& Shi, L. (2019). The Way of the International Cooperation of Higher Education Under the Strategy of "The Belt and Road. Science Journal of Education, 7(3), 73-80.

Karagiorgi, Y., \& Nicolaidou, M. (2013). Professional development of teacher educators: Voices from the Greek-Cypriot context. Professional Development in Education, 39(5), 784-798.

Khumalo, S. S. (2021). A critical examination of the recruitment processes of the South African principals from Rawls perspective: A conceptual argument. Cogent Social Sciences, 7(1), 1918879.

Kilatsih, E., Saam, Z., \& Sumarno, S. (2020). Pemetaan Dan Pemerataan Guru Berdasarkan Beban Mengajar Guru Smp Negeri Di Kecamatan Tenayan Raya Pekanbaru. Jurnal Manajemen Pendidikan Penelitian Kualitatif, 3(1), 1-7.

Krismiyati, K. (2017). Pengembangan Sumber Daya Manusia dalam Meningkatkan Kualitas Pendidikan di SD Negeri Inpres Angkasa Biak. Jurnal Office, 3(1), 43-50. 
Latiana, L. (2019). Peran Sertifikasi Guru Dalam Meningkatkan Profesionalisme Pendidik. Edukasi, 13(1).

Leonard, L. (2016). Kompetensi tenaga pendidik di Indonesia: Analisis dampak rendahnya kualitas SDM guru dan solusi perbaikannya. Formatif: Jurnal Ilmiah Pendidikan MIPA, 5(3).

Lestari, L. W. D., \& Nugroho, B. Y. (2021). Implementasi Kebijakan Tata Kelola Guru Pns Pada Tingkat Sekolah Dasar Dalam Rangka Penyediaan Guru Secara Merata Di Kabupaten Malang. Media Bina Ilmiah, 15(11), 5705-5716.

Liu, X., Wu, J. P., \& Zheng, X. (2021). An Analysis of the Dilemma and Strategy of Foreign Student Education in China. Contemporary Education and Teaching Research, 2(1), 42-45.

Miles, M. H., \& Saldana, J. (2014). Describing Variability In: Qualitative Data Analysis: A Methods Sourcebook.

Nurfalah, F. (2021). Communication Strategy of The Department of Youth, Sports, Culture and Tourism in Revitalization the Water Park Cave Sunyaragi Cirebon City, Indonesia. European Journal of Molecular \& Clinical Medicine, 7(10), 2319-2326.

Ozarkiv, O. M., \& Yakovenko, M. L. (2020, September). Safety strategy as an essential resource for forming modern marine corporate culture in maritime education standards. IOP Conference Series: Materials Science and Engineering (Vol. 918, No. 1, p. 012178). IOP Publishing.

Pan, R., Yang, M., \& Chen, Z. (2020, December). Research on the Teaching Methods of Integrating Chinese Culture into College English Teaching under the Strategy of "Chinese Culture Going Global." In 2020 6th International Conference on Social Science and Higher Education (ICSSHE 2O2O) (pp. 1042-1046). Atlantis Press.

Priambodo, Y. A., \& Prasetyo, S. Y. J. (2018). Pemetaan Penyebaran Guru di Provinsi Banten dengan Menggunakan Metode Spatial Clustering K-Means (Studi kasus: Wilayah Provinsi Banten). Indonesian Journal of Computing and Modeling, 1(1), 18-27.

Puspita, I. R., Noor, H. M., \& Erawan, E. (2020). Peran Dinas Pendidikan Dan Kebudayaan Provinsi Kalimantan Timur Dalam Meningkatkan Kualitas Guru Sekolah Menengah Kejuruan (Smk) Di Kota Samarinda. Jurnal Administrasi Publik, 8(1).

Putri, S. A. A. K., \& Karwanto, K. (2021). Sistem Rekrutmen Guru Dalam Upaya Meningkatkan Mutu Pendidikan. Inspirasi Manajemen Pendidikan, 9(1), 229-239.

Qomarani, L. N. (2020). The Anomaly of The Presence of Government Employees with the Employment Agreement (PPPK) In the Employment Horizon in Indonesia. Cephalon, 4(2), 95-110.

Rajaloa, N. I., \& Hasyim, R. (2018). Manajemen Perencanaan Dan Rekrutmen Tenaga Pendidik Oleh Dinas Pendidikan Kota Ternate. Edukasi, 16(1), 11-28.

Robert, S., \& Melinda, T. (2018). Pengaruh Motivasi dan Kepemimpinan Terhadap Kinerja Karyawan. Media Mahardhika, 16(3), 456-463.

Salusu, J. (2008). Pengambilan Keputusan Strategik untuk Organisasi Publik dan Organisasi NonProfit. Grasindo.

Sangkereng, W., Engka, D. S., \& Sumual, J. I. (2019). Faktor-faktor yang Mempengaruhi Indeks Pembangunan Manusia di Provisi Sulawesi Utara. Jurnal Berkala Ilmiah Efisiensi, 19(04), 60-71.

Singh, P., Hoyte, F., Heimans, S., \& Exley, B. (2021). Teacher Quality and Teacher Education: A Critical Policy Analysis of International and Australian Policies. Teacher Quality and Teacher Education: A Critical Policy Analysis of. Australian Journal of Teacher Education, 46(4). 
Al- Ishlah: Jurnal Pendidikan, December 2021, 13 (3), Pages 2575-2584

Rahmawati Sururama, Valentino Christ Vowell

This page is intentionally left blank 